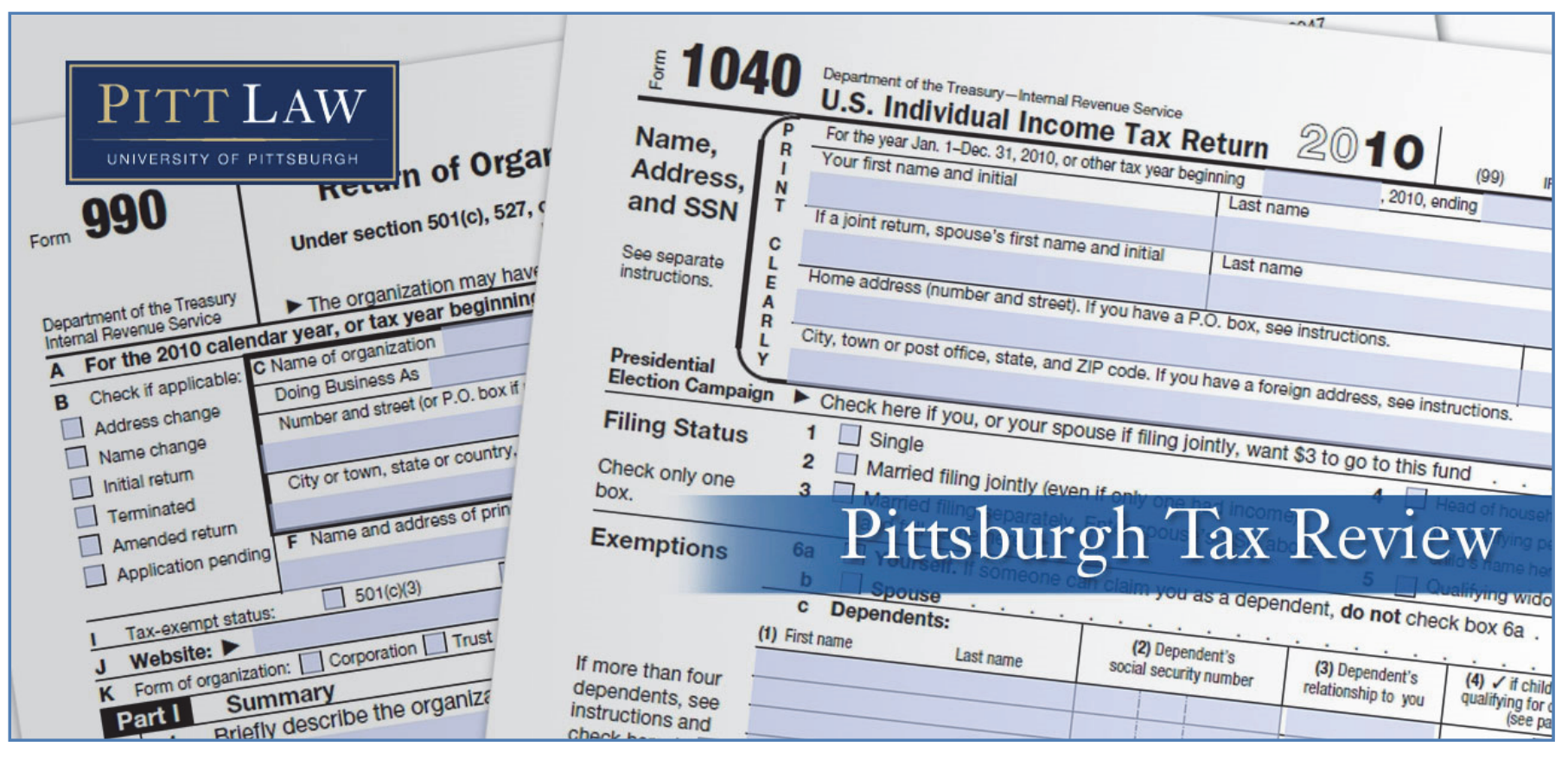

Volume 16 (2018) | ISSN 1932-1821 (print) 1932-1996 (online)

DOI 10.5195/taxreview.2018.80 | http://taxreview.law.pitt.edu

\title{
RETHINKING THE OBVIOUS: CHOICE OF ENTITY AFTER THE TAX CUTS AND JOBS ACT
}

\author{
Leo N. Hitt
}

\section{(cc) EY-NO-ND}

This work is licensed under a Creative Commons Attribution-Noncommercial-No Derivative Works 3.0 United States License.

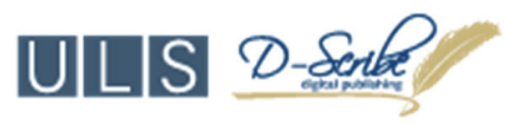

This journal is published by the University Library System of the University of Pittsburgh as part of its D-Scribe Digital Publishing Program, and is cosponsored by the University of Pittsburgh Press. 


\title{
RETHINKING THE OBVIOUS: CHOICE OF ENTITY AFTER THE TAX CUTS AND JOBS ACT
}

\author{
Leo N. Hitt ${ }^{*}$
}

The Tax Cuts and Jobs Act $^{1}$ (TCJA) was passed by Congress on December 20, 2017, signed by the President on December 22, 2017, and is generally effective January $1,2018 .^{2}$ The TCJA enacted dramatic changes to the calculation of taxes for both individual and corporate taxpayers. One of the most significant impacts of this legislation was to substantially reduce the rate of taxation on corporations (from a maximum rate of $35 \%$ to a flat rate of $21 \%)^{3}$ while only minimally reducing the rate of taxes on individuals (from a maximum rate of $39.7 \%$ to a maximum rate of $37.5 \%$ ). ${ }^{4}$ Some of the assumptions that have formed the basis for choice-of-entity analysis may have shifted significantly following passage of the TCJA. At this time, tax advisors should test what they think they know in order to make sure that old wisdom has continuing validity in the new environment after the TCJA.

This article will set forth, in fairly summary fashion, the general factors that advisors consider in making entity-choice decisions. After a presentation of the factors, the tax impact of the choice-of-entity decision that advisors considered prior to the TCJA will be reviewed, not as a history lesson but as a template for a comparative analysis under current law. Following the discussion of the prior law analysis, a discussion of the relevant provisions

\footnotetext{
${ }^{*}$ Mr. Hitt is a Partner of Reed Smith LLP in its Pittsburgh, PA office and an adjunct professor of law at the University of Pittsburgh School of Law.

${ }^{1}$ Tax Cuts and Jobs Act, Pub. L. No. 115-97, 131 Stat. 2054 (2017).

${ }^{2}$ E.g., id. $\S 11001(\mathrm{c}), 131$ Stat. at 2059 (codified at § 1(j)(1)); MOLLY F. SHERLOCK \& DonALD J. Marples, Cong. Research Serv., R45092, The 2017 TAX REvision (P.L. 115-97): COMPARISON tO 2017 TAX LAW 1, 3 (2018), https://fas.org/sgp/crs/misc/R45092.pdf.

${ }^{3}$ Tax Cuts and Jobs Act $\S 13001$ (a), 131 Stat. at 2096 (codified at $\S 11(b)$ ).

${ }^{4} I d$. $\S 11001$ (a), 13001(a), 131 Stat. at 2054, 2096 (codified at $\S \S 1(\mathrm{j}), 11(\mathrm{~b})$ ).
}

Pitt Tax Review | ISSN 1932-1821 (print) 1932-1996 (online) DOI 10.5195/taxreview.2018.80 | http://taxreview.law.pitt.edu 


\section{8 |Pittsburgh Tax Review | Vol. 162018}

of the TCJA and a revised matrix for analyzing entity choice will be presented. $^{5}$

\section{GENERAL CONSIDERATIONS}

The list of "usual suspects" in an entity-choice analysis includes the following types of ownership:

- Direct ownership (fee simple or joint tenancies), often described as sole proprietorships and co-ownerships;

- General partnerships;

- Limited partnerships;

- General or limited partnerships that have made the election to be treated as limited liability partnerships;

- $\quad$ Limited liability companies (LLCs);

- Corporations; and

- Other entities.

There are other more esoteric forms of ownership recognized under the Internal Revenue Code of 1986 (Code), such as real estate investment trusts, ${ }^{6}$ real estate mortgage investment conduits, ${ }^{7}$ and regulated investment companies $^{8}$ that apply in fairly limited situations. This article will not address these exotic forms of ownership, as they are beyond the scope of the traditional choice-of-entity analysis performed by most lawyers, accountants, and other business advisors. Also, this article will not include a discussion of non-U.S. entity choice, as to which there may be differences that depend on the local law of the home jurisdiction.

The factors that are traditionally used to analyze which entity form best suits a particular business or investment arrangement include: liability limitation; federal, state, and local income tax implications; exit strategies;

${ }^{5}$ See generally Leo N. Hitt \& Jeffrey D. Eicher, Choice of Entity Under the Tax Cuts and Jobs Act of 2017, TAXES, May 2018, at 33.

${ }^{6}$ I.R.C. $\S \S 856-859$.

${ }^{7} I d . \S \S 860 \mathrm{~A}-860 \mathrm{G}$.

${ }^{8} I d . \S \S 851-855$.

Pitt Tax Review | ISSN 1932-1821 (print) 1932-1996 (online) DOI 10.5195/taxreview.2018.80 | http://taxreview.law.pitt.edu 
and other relevant factors. The importance of each of these factors may vary from situation to situation and, in certain instances, from owner to owner. While the discussion below presents certain "other relevant factors," this list is far from complete. It is incumbent upon the advisor in a choice-of-entity discussion to identify the drivers that are relevant to the particular owners and businesses.

An important observation for the reader to consider deals with the classification of entities for tax purposes as differentiated from their status under applicable organizational law. As discussed below, ${ }^{9}$ an entity's status under state organizational law as an LLC, partnership, or corporation is not always determinative of its tax status. Except for those entities that are classified as "automatic" corporations under Treasury Regulation section 301.7701-3(a), business entities are eligible to elect to be taxable as (1) a corporation or (2) a disregarded entity (for an entity with one owner) or a partnership (for an entity with more than one owner). For the most part (with the exception, primarily, of the discussion of liability limitation that follows this paragraph), this article is concerned with the entity's tax status, rather than its status under state organizational law. References herein to "tax law partnerships" and "tax law corporations" are designed to highlight this distinction.

\section{A. Liability Limitation}

In all forms of ownership, claimants and creditors may proceed against the assets of the business entity. The issue that liability limitation raises is whether a claimant or creditor of the business can attach the owner's assets outside of the business entity. Liability limitation is a fundamental consideration that is, or should be, important to all of the owners. Usually, liability protection is most important for investor owners (those who are committing financial resources only) and substantial liability limitation is typically a sine qua non ${ }^{10}$ of the potential investor-owner's investment. Owners who are operators of the business are sometimes less concerned with

\footnotetext{
${ }^{9}$ See infra Part I.B.

10 "An indispensable condition or thing; something on which something else necessarily depends." Sine qua non, BLACK's LAW DiCTIONARY (10th ed. 2014).
}

Pitt Tax Review | ISSN 1932-1821 (print) 1932-1996 (online) DOI 10.5195/taxreview.2018.80 | http://taxreview.law.pitt.edu 
liability limitation (although they are often not indifferent to gaining some level of protection). To the extent that operator-owners or their spouses have substantial resources outside of the entity under consideration, they will likely be increasingly concerned with the ability to limit their liability from the operations of a business entity to the assets of that entity. ${ }^{11}$

The lack of liability limitation will usually result in the quick elimination of sole proprietorships, co-ownerships, and general partnerships as viable entity choices for conducting business operations that have any degree of exposure to risk of liability from the business's creditors or claimants. Other reasons to reject these "simpler" forms of ownership include the difficulty in disposing of an interest in a business when each asset has to be transferred (with retitling and transfer taxes often adding to the awkwardness of such a transfer). As a result, the three most common choices for a vehicle to operate a business or hold investments are corporations, limited partnerships, and LLCs. ${ }^{12}$

All three of the primary entity choices (corporations, limited partnerships, and LLCs) provide excellent liability protection for their owners. ${ }^{13}$ Corporations and LLCs shield all of their owners from potential liability beyond the entities' assets. ${ }^{14}$ Limited partnerships provide liability limitation for their limited partners, but expose the general partner to unlimited liability for obligations of, and claims made against, the entity. ${ }^{15}$ For this reason, it is typical to use a corporation or LLC to act as the general partner of a limited partnership, so that the unlimited liability of the general partner is protected by the liability shield of a corporation or LLC. ${ }^{16}$

In general, the liability limitation of each of the primary vehicles is comparable, but there are some differences that should be reviewed before

\footnotetext{
${ }^{11}$ Note that there are certain types of liabilities for which protection may not be available, such as certain environmental-related liabilities under the Comprehensive Environmental Response, Compensation, and Liability Act of 1980 § 107(a) (CERCLA), 42 U.S.C. § 9607(a) (2012).

${ }^{12}$ See Robb Mandelbaum, What's the Best Corporate Structure to Protect Small Business Owners?, TIME (July 21, 2016), https://www.time.com/money/4394075/best-structure-small-businesses/.

${ }^{13} \mathrm{Id}$.

${ }^{14}$ See id.

${ }^{15} \mathrm{Id}$.

${ }^{16} I d$.
}

Pitt Tax Review | ISSN 1932-1821 (print) 1932-1996 (online) DOI 10.5195/taxreview.2018.80 | http://taxreview.law.pitt.edu 
making a final selection on the basis of liability limitation. Corporations, including S corporations, have the best precedent under applicable state law for protecting owners from liability. ${ }^{17}$ However, because certain formalities may have to be satisfied in order to gain full protection under applicable corporate statutes ${ }^{18}$ and because those formalities are generally not present for limited partnerships or LLCs, ${ }^{19}$ there is potentially greater risk of "piercing the veil" for a corporation if there is a failure on the part of its officers, directors, or shareholders to satisfy certain corporate formalities, such as annual meetings.

As the use of LLCs has become more prevalent, ${ }^{20}$ advisors have become increasingly more comfortable with the quality of protection that is provided under applicable state law (i.e., in the state of organization of the entity, the state(s) in which operations exist, and the state of residence of the owners). There is improving precedent on the subject of the quality of protection provided to LLCs under state law. ${ }^{21}$ In fact, there are some authors who make the argument that there is a lower risk of piercing the veil with $\operatorname{LLCs}^{22}$ because there are far fewer organizational formalities required under most LLC statutes compared to corporate statutes. ${ }^{23}$

There are two issues commonly associated with the liability shield granted by limited partnerships. First, a general partner must accept unlimited

\footnotetext{
${ }^{17}$ E.g., Citizens United v. FEC, 558 U.S. 310, 351 (2010) (stating that state law grants corporations special advantages such as limited liability).

${ }^{18}$ See Jonathan Macey \& Joshua Mitts, Finding Order in the Morass: The Three Real Justifications for Piercing the Corporate Veil, 100 CORNELL L. REV. 99, 109 (2014).

${ }^{19}$ See, e.g., 15 PA. CONS. STAT. $\S 8611-8695,8811-8885$ (2016).

${ }^{20}$ All fifty states and the District of Columbia have LLC statutes that recognize the liability protection of an LLC. Nicholas G. Karambelas, Revised Uniform Limited Liability Company Act, D.C. BAR: WASH. LAW., https://www.dcbar.org/bar-resources/publications/washington-lawyer/articles/ february-2008-llc-act.cfm (last visited Nov. 16, 2018).

${ }^{21}$ See, e.g., NetJets Aviation, Inc. v. LHC Commc'n, LLC, 537 F.3d 168, 183 (2d Cir. 2008) (applying Delaware veil-piercing law to LLCs).

${ }^{22}$ See, e.g., 2 LARry E. RiBSTEIN \& RoBert R. KeAtinge, RiBStein AND KEATINGE ON Limited LiABILITY COMPANIES $\S 12: 3$ (2d ed. 2011, rev. ed. 2018).

${ }^{23}$ NetJets Aviation, 537 F.3d at 178.
}

Pitt Tax Review | ISSN 1932-1821 (print) 1932-1996 (online) DOI 10.5195/taxreview.2018.80 | http://taxreview.law.pitt.edu 
liability for the entity's obligations and other liabilities. ${ }^{24}$ In fact, because only general partners are liable for the entities' obligations (beyond the limited partners' agreed capital investment in the partnership), that liability is, in a sense, a leveraged liability because general partners bear limited partners' share of the entities' liabilities in addition to their own.

The second liability limitation issue often associated with a limited partnership is the concern that a limited partner may lose liability protection if the limited partner acts in a way that causes the limited partner to be treated as a general partner. ${ }^{25}$ The scope of permitted actions of the limited partner(s) varies significantly from jurisdiction to jurisdiction. ${ }^{26}$ While the business can choose to organize in a modern jurisdiction that gives the limited partner the greatest possible shield, the general partner argument remains an issue for businesses that operate as limited partnerships in more than one jurisdiction where such broad protection may not be available for limited partners. ${ }^{27}$

A fairly recent development under many state laws is the ability of a partnership, general or limited, to make a limited liability partnership (LLP) or a limited liability limited partnership (LLLP) election. ${ }^{28}$ Although either a general partnership or a limited partnership may make this election, the utility of the election to the partners should be reviewed prior to making the election because of its fairly narrow coverage. The "limited liability" of LLP or LLLP statutes refers to a specific type of liability protection (tort-based liability) as opposed to other types of potential liability. The partners of a LLP or LLLP are protected from tort liability that arises from the actions of other owners and employees within the partnership, except for their own actions and the

${ }^{24}$ UNIF. LTD. P'ShIP ACT § 404(a) (UNIF. LAW COMM’N 2001).

${ }^{25}$ Although the 2001 amendment to the Uniform Limited Partnership Act increases the risk of liability to the general partner by reducing the limited partner's liability under section 303(a), the current version "does not prevent a limited partner from being liable for its own conduct when a third party asserts that a limited partner's own wrongful conduct has injured the party.” Lauris G.L. Rall, A General Partner's Liability Under the Uniform Limited Partnership Act, 37 SUFFOLK U. L. REV. 913, 917 (2004).

${ }^{26}$ E.g., Shimko v. Guenther, 505 F.3d 987, 990 (9th Cir. 2007) (reasoning that third party who knows or should know that a person is not a general partner cannot claim damage based on conduct); $c f$. In re Adelphia Commc'ns Corp., 376 B.R. 87, 93 (Bankr. S.D.N.Y. 2007) (holding the limited partner liable to a creditor who knew of the limited partner status, despite Delaware statute).

${ }^{27}$ E.g., Shimko, 505 F.3d at 990; cf. In re Adelphia Commc'ns Corp., 376 B.R. at 93.

${ }^{28}$ See, e.g., 15 PA. CONS. STAT. $\S 8201-8249$ (2016).

Pitt Tax Review | ISSN 1932-1821 (print) 1932-1996 (online)

DOI 10.5195/taxreview.2018.80 | http://taxreview.law.pitt.edu 
actions of those whom they directly supervise. ${ }^{29}$ This election should be considered for businesses that have meaningful exposure to tort liability based on their operations, particularly in the case of service partnerships. ${ }^{30}$

\section{B. Federal Tax Treatment}

Entities organized as corporations under applicable law (including certain foreign entities) are treated "automatically" as corporations for U.S. federal income tax purposes ${ }^{31}$ and have no ability to elect a different status. ${ }^{32}$ Partnerships (general and limited) and LLCs are "check-the-box" entities. ${ }^{33}$ Under the regulations, they are treated as either partnerships or disregarded entities (depending on the number of owners), or as corporations (a $\mathrm{C}$ or $\mathrm{S}$ corporation depending on whether the $\mathrm{S}$ election is available and made). ${ }^{34}$ The default status for a domestic "check-the-box" entity is either a disregarded entity (for an entity with a single owner) or a partnership (for an entity with multiple owners). If the entity's owners wish to adopt corporate status, they have to make an affirmative election on I.R.S. Form $8832 .{ }^{35}$

A single-owner check-the-box entity that is not a corporation is disregarded for federal income tax purposes. ${ }^{36}$ The assets, debts, and operations of any business or investment activity owned or operated by a disregarded entity are treated as if there was no intervening entity, and thus

${ }^{29}$ Id. $\S 8204(\mathrm{~b})$.

${ }^{30}$ See id. $\S 8995-8998$.

${ }^{31}$ Treas. Reg. § 301.7701-2(b)(1)-(8) (as amended in 2016).

${ }^{32}$ Note that corporations meeting certain shareholder and stock requirements may elect to be taxed as S corporations under $\S 1362(\mathrm{a})(1)$. S corporation status, when available, allows the shareholders to have tax treatment that is somewhat similar to partners in a partnership. I.R.C. § 1362(a)(1).

${ }^{33}$ Treas. Reg. $\S 301.7701-3$ (a) (as amended in 2006). Under the regulation, such entities are referred to as "eligible entities." Id.

${ }^{34}$ See id.

${ }^{35} I d$. $\$ 301.7701-3(\mathrm{c})(1)(\mathrm{i})$.

${ }^{36} I d$. $\$ 301.7701-3$ (a).

Pitt Tax Review | ISSN 1932-1821 (print) 1932-1996 (online) DOI 10.5195/taxreview.2018.80 | http://taxreview.law.pitt.edu 
are treated as those of the single owner. ${ }^{37}$ There is no federal income tax imposed on a disregarded entity. ${ }^{38}$

An eligible entity with multiple owners that is not a corporation is treated as a partnership for federal income tax purposes. ${ }^{39}$ A tax law partnership is recognized for federal income tax purposes, but it is not subject to federal income tax on entity-level earnings. ${ }^{40}$ Only the partners of the tax law partnership are subject to tax on its entity-level earnings. ${ }^{41}$ In addition, the partnership tax rules ${ }^{42}$ allow for flexible "allocation of income, gain, loss, deduction, [and] credit[s]" under $\S 704(\mathrm{~b})$, subject to meeting certain regulatory requirements regarding the "substantial economic effect" of such allocations. ${ }^{43}$ In a business or investment arrangement where the owners have different economic positions in the entity, the ability to specially allocate taxrelated items among the owners can be a very powerful tool to reflect the agreed economics of the parties.

Additionally, tax law partnerships pass through entity-level debt basis for purposes of claiming losses. As a result, partners' bases includes all partnership liabilities under $\S \S 705(a)$ and $752(a)-(b) .{ }^{44}$ Because of the passthrough of losses and debt basis, certain limitations have been added to the Code over time that are designed to restrict the ability of partners to claim

${ }^{37}$ Id. $\S 301.7701-3(\mathrm{~b})$.

${ }^{38}$ A disregarded entity for federal income tax purposes may be recognized for purposes of other taxes, including employment taxes, state taxes, and foreign taxes. See, e.g., id. §301.7701-1(a)(1) (as amended in 2011), -2(b)(8), (c)(2)(iv)(B) (as amended in 2016).

${ }^{39} \mathrm{Id}$. $\$ 301.7701-3$ (b)(ii) (as amended in 2006).

${ }^{40} I d$.

${ }^{41} I d$.

${ }^{42}$ I.R.C. $\S \S 701-761$.

${ }^{43}$ See Treas. Reg. § 1.704-1(b)(1)(i) (as amended in 2017).

${ }^{44}$ In broad terms, the regulations under $\S 752$ allocate partnership debt for basis purposes based on share of risk for recourse liabilities and share of profits for nonrecourse liabilities. Id. $\S \S 1.752-1$ (as amended in 2005), -7 (2005).

Pitt Tax Review | ISSN 1932-1821 (print) 1932-1996 (online) DOI 10.5195/taxreview.2018.80 | http://taxreview.law.pitt.edu 
losses that are leveraged ${ }^{45}$ and those that are attributable to activities in which the partners do not materially participate. ${ }^{46}$

Tax law partnerships are permitted to use a flexible compensation tool known as a "profits interest." ${ }^{47}$ Profits interests are economic interests in a partnership that can be related to different types of income streams from the partnership, including operating income, divisional profits, and capital transactions. ${ }^{48}$ If structured properly, profits interests receive favorable treatment under U.S. tax law, including no taxable income on grant, immediate pass-through participation with no exercise payment requirement, the ability to add vesting requirements, no dollar amount limitations, and the ability to recognize long-term capital gains on pass-through gains and dispositions of interests. ${ }^{49}$ Some of these attributes make the use of profits interests, as a compensation tool, preferable to the issuance of an incentive stock option (an "ISO") by a corporation. ${ }^{50}$ It should be noted that the TCJA has limited the ability of a profits interest holder to receive pass-through capital gain treatment, as discussed below. ${ }^{51}$

If an entity is taxable as a corporation, either as a result of its automatic characterization or an election under the check-the-box regime, and cannot or does not elect S corporation status under $\S 1362$ (a), then there is no flowthrough of income or losses to the investors because the corporation is both recognized for tax purposes and is treated as a separate taxable entity. However, utilizing a corporation produces income that could be subject to a second set of rate brackets, which could reduce the effective rate of tax on such income (subject to certain limitations for affiliated corporations, ${ }^{52}$

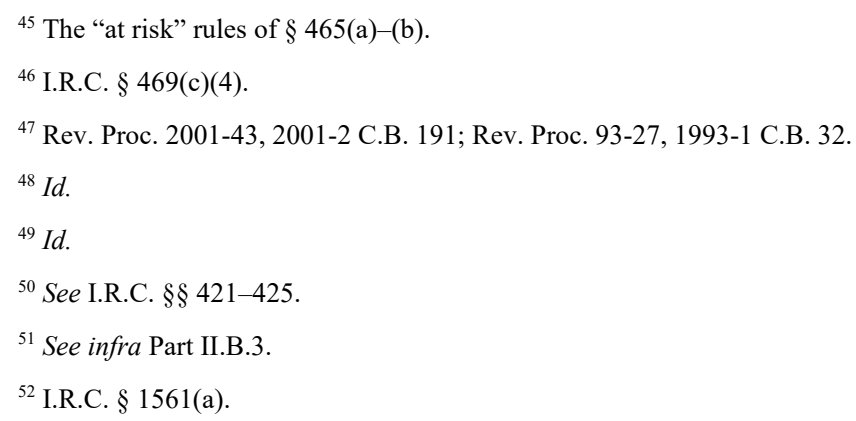

Pitt Tax Review | ISSN 1932-1821 (print) 1932-1996 (online) DOI 10.5195/taxreview.2018.80 | http://taxreview.law.pitt.edu 
personal holding companies, ${ }^{53}$ and the accumulated earnings tax ${ }^{54}$ ) because of the availability of multiple sets of lower tax brackets resulting from having more than one taxpayer recognizing the income. In addition, as discussed below, ${ }^{55}$ the TCJA has substantially reduced the rate of tax on corporate taxpayers.

Another area in which tax law partnerships and disregarded entities are more favorably treated than corporations is with regard to the tax consequences of a distribution of assets to the owners of the entity. It can be desirable to move assets in an entity to some or all of its owners in a number of different contexts. For instance, assets may be distributed to owners in order to purchase some or all of the equity interest of an owner or owners, to pay an in-kind dividend or current distribution to its owners, to divide a business among its owners, or to completely or partially liquidate the business or investment assets of the entity. The distribution of cash and noncash assets owned by a tax law corporation will usually result in double taxation at the entity and owner levels, with the extremely limited exception of a tax-deferred corporate division under $\S 355$ (a). On the other hand, a distribution of noncash assets by a tax law partnership is generally tax-free under $\S 731$ (a) to both the partnership and its partners, subject to exceptions for the distribution of marketable securities under $\S 731(\mathrm{~b})$ and a shift in certain hot assets under $\S 751(\mathrm{~b})$. A distribution by a disregarded entity is always treated as a nontaxable nonevent because the owner of the entity is treated as the owner of all of the assets of the entity before and after the distribution. ${ }^{56}$

Factors in favor of choosing to be a tax law corporation include avoiding the passive loss rules of $\S 469$ and the at risk rules of $\S 465$, which are generally not applicable to corporations except for certain closely held corporations and personal service corporations. ${ }^{57}$ Other advantages to utilizing tax law corporations include the availability of tax-deferred

\footnotetext{
${ }^{53} I d . \S 541$.

${ }^{54} I d . \S 531$.

${ }^{55}$ See infra Part II.A.1.

${ }^{56}$ See Treas. Reg. § 301.7701-2(c)(2)(i) (as amended in 2016).

${ }^{57}$ See I.R.C. $\S \S 465(c), 469(a)(2)(B)-(C)$.
}

Pitt Tax Review | ISSN 1932-1821 (print) 1932-1996 (online) DOI 10.5195/taxreview.2018.80 | http://taxreview.law.pitt.edu 
reorganizations ${ }^{58}$ and ISOs. ${ }^{59}$ However, the major tax disadvantage to being a corporation taxed under Subchapter C of the Code (a "C corporation") is the so-called double tax on dividend and liquidation distributions. The reduction in corporate tax rates made by the TCJA when combined with the reduced maximum rate on most (but not all) dividends to $20 \%{ }^{60}$ has lessened the burden of the double tax significantly and, in some cases, entirely, as discussed below. ${ }^{61}$

As briefly mentioned above, certain corporations have the ability to elect to be taxed as $\mathrm{S}$ corporations. The ability of a corporation to elect $\mathrm{S}$ corporation status under $\S 1362(a)(1)$ depends upon satisfying a number of requirements, including the nature and number of shareholders and the existence of a single class of stock (except for differences in voting power) ${ }^{62}$ If the $\mathrm{S}$ corporation election is validly made, the $\mathrm{S}$ corporation and its shareholders are taxed in a manner that is similar to the taxation of a partnership and its partners. ${ }^{63}$

There are advantages and disadvantages when the taxation of $\mathrm{S}$ corporations and their shareholders are compared to that of a tax law partnership and its partners. Principal disadvantages when an S corporation is compared to a partnership include, among others: (1) the possibility of involuntary termination of an $\mathrm{S}$ corporation election due to changes in number or types of shareholders; (2) the inability to have multiple classes of ownership (except for voting class distinctions); (3) the lack of flexibility in allocations as an S corporation's pass-through of income, gain, deductions, losses, and credits is on a per share/per day basis; (4) the inability to remove assets from the $\mathrm{S}$ corporation without triggering income tax (at one level of tax usually, but still with accelerated gain recognition when compared to a

\footnotetext{
${ }^{58}$ See infra Part I.C.

${ }^{59}$ Profits interests are a potentially more powerful alternative to an ISO because of immediate participation without the requirement of making an exercise payment and the absence of dollar limitations on awards.

${ }^{60}$ I.R.C. $\S 1(\mathrm{~h})(1)(\mathrm{D})$.

${ }^{61}$ See supra Part III.

${ }^{62}$ Treas. Reg. § 1.1361-1(b)(i)-(iv) (as amended in 2008).

${ }^{63}$ But see I.R.C. $\S \S 1374-1375$ (imposing entity level taxes upon S corporations that were formerly C corporations).
}

Pitt Tax Review | ISSN 1932-1821 (print) 1932-1996 (online) DOI 10.5195/taxreview.2018.80 | http://taxreview.law.pitt.edu 
partnership); and (5) the inability to include entity-level debt in the investor's basis for the purpose of distributions and loss allocations. ${ }^{64}$ Some of the advantages of the $\mathrm{S}$ corporation model are: (1) the availability of tax-deferred reorganizations under $\S \S 351$ and 368 as an exit strategy, ${ }^{65}$ (2) the inapplicability of the so-called hot asset provision under $\S 751(\mathrm{~b})$ which may convert capital gains upon the disposition of a partnership interest or certain distributions to ordinary income; and (3) the ability to minimize Social Security tax and/or self-employment tax, as discussed below.

While the major focus of this article is on federal income taxes, it is important to consider the application of self-employment tax (SECA tax) ${ }^{66}$ and Social Security tax (FICA tax ${ }^{67}$ on the owners of the business or investment vehicle, as these taxes may have a significant impact on the choice-of-entity analysis. A tax law corporation, either an S corporation or a $\mathrm{C}$ corporation, generally has the most favorable treatment for purposes of Social Security taxes. Only the salary of a C corporation employee (whether or not a shareholder) is subject to the FICA tax. Similarly, the SECA tax is not applicable to a $\mathrm{C}$ corporation employee. The income of an $\mathrm{S}$ corporation, which passes through to a shareholder, is not subject to SECA tax, as long as the $\mathrm{S}$ corporation pays adequate compensation (which would be subject to FICA tax). The balance of the S corporation's income allocable to the shareholder on a pass-through basis would not be subject to SECA tax. It is not clear what standards apply to determine when compensation is "adequate" for this purpose. ${ }^{68}$

The treatment of tax law partnerships and their partners under these employment tax rules is less certain than that of S corporations and their shareholders. Section 1402(a)(13) provides an exemption for income allocated to limited partners in partnerships except for guaranteed payments made to limited partners for services rendered by them to the partnership. Under Proposed Regulation section 1.1402(a)-2, the terms "limited partner"

\footnotetext{
${ }^{64}$ Treas. Reg. § 1.1361-1 (as amended in 2008).

${ }^{65}$ See infra Part I.C.

${ }^{66}$ I.R.C. $\S 1402$.

${ }^{67}$ Id. $\S \S 3101-3128$.

${ }^{68}$ See I.R.S. Priv. Ltr. Rul. 95-30-005 (Apr. 26, 1995); see also Ding v. Comm'r, 74 T.C.M. (CCH) 708, 1997 T.C.M. (RIA) ๆ 97,435 (1997), aff'd, 200 F.3d 587 (9th Cir. 1999).
}

Pitt Tax Review | ISSN 1932-1821 (print) 1932-1996 (online) DOI 10.5195/taxreview.2018.80 | http://taxreview.law.pitt.edu 
and "partnership" are extended to include owners in other unincorporated entities, such as LLCs, that are treated as tax law partnerships if certain conditions are met. ${ }^{69}$ If the owner of an interest in the entity is a service partner in a service partnership, all allocable income is subject to the SECA tax. $^{70}$ A service partnership is defined as one that renders professional services, such as law, accounting, engineering, actuarial services, consulting, and so on. ${ }^{71}$ If the entity is not a service partnership, limited partners are not subject to the SECA tax, while general partners are subject to the SECA tax. ${ }^{72}$ Limited partners in nonpartnership entities are defined as owners who have no contract signing authority, work no more than 500 hours for the entity, and are not personally liable for entity debt under state law. ${ }^{73}$ General partners may be able to bifurcate their interests and qualify for exemption from the SECA tax as limited partners if they do not exceed the 500-hour test, the partnership has at least two classes of interests, and persons who are limited partners only own at least $20 \%$ of the interests in the "other" class (presumably the other limited partner(s) could include a spouse or spouses of the general partner(s)). ${ }^{74}$ Note that, as a proposed regulation, this rule has limited value as an authority and is more readily subject to a change in position by the IRS than a final regulation.

\section{Exit Strategy}

One of the key issues often not discussed at the formation of an entity is the exit strategy for all or any of the investors. This failure is understandable to some degree because of the enthusiasm associated with beginning a business or investment activity. However, not considering exit issues may lead to problems for the owners and the business when one or more, but not all, of the owners wish to depart the entity, or upon a disposition of the entire

\footnotetext{
${ }^{69}$ Computation of Net Earnings from Self-Employment, Prop. Treas. Reg. § 1.1402(a)-2(f), 19971 C.B. 770,772 .

${ }^{70}$ Id. $\S 1.1402(\mathrm{a})-2(\mathrm{~h})(5), 1997-1$ C.B. at 772.

${ }^{71} I d . \S 1.1402(\mathrm{a})-2(\mathrm{~h})(6)(\mathrm{iii})$.

${ }^{72} I d$. $\$ 1.1402(\mathrm{a})-2(\mathrm{~g})$.

${ }^{73} \mathrm{Id} . \S 1.1402(\mathrm{a})-2(\mathrm{~h})(2)$.

${ }^{74} I d . \S 1.1402(\mathrm{a})-2(\mathrm{~h})(4)$.
}

Pitt Tax Review | ISSN 1932-1821 (print) 1932-1996 (online) DOI 10.5195/taxreview.2018.80 | http://taxreview.law.pitt.edu 
business or investment activity. There are some significant differences between the treatment of the sale of the assets or interests in tax law corporations compared with the treatment of a pass-through vehicle (i.e., a tax law partnership, a disregarded entity, or an S corporation), as well as some differences among the various types of pass-through entities.

In the event of a taxable asset sale by the entity, the owners of the entity are typically in a far better position for tax purposes if the entity is a tax law pass-through entity. The benefit is attributable to the fact that the gain on the asset sale is usually taxable at the owner level and not at the entity level. ${ }^{75}$ If a corporation sells its assets in a taxable sale, unless it has significant usable tax attributes (such as net operating losses), the corporation will be subject to tax upon the asset $\operatorname{sale}^{76}$ and the shareholders will be taxed upon the distribution of the proceeds of the sale. ${ }^{77}$

The selling owners of the entity will often have a preference for structuring a potential sale as a sale of interests in the entity rather than a sale of its assets. The existence and degree of preference depends, in large part, on the tax characterization of the entity. If the entity is classified as a tax law corporation, structuring the transaction as a sale of interests in the entity allows for the avoidance of the double tax, discussed above. ${ }^{78}$ On the other hand, the buyer of interests in a tax law corporation is typically unable to obtain a tax efficient step-up in the bases of the assets of that corporation unless the corporation makes a valid deemed-asset-sale election under either $\S 338(\mathrm{~h})(10)$ or $\S 336(\mathrm{e})$. If the selling entity is a partnership, there is usually a partial look-through to the character of its assets for determining capital versus ordinary treatment under the "hot asset" provisions of $\S 751(\mathrm{~b})$, so the selling partners may be indifferent to whether the transaction is structured as an asset sale or a stock sale. Similarly, the buyer(s) may be indifferent to

\footnotetext{
${ }^{75}$ There is an exception to this tax rule. $\mathrm{S}$ corporations that have built-in gain attributable to when the $\mathrm{S}$ corporation was a $\mathrm{C}$ corporation within five years prior to the sale or when the $\mathrm{S}$ corporation acquired any of its assets from a $\mathrm{C}$ corporation in a nontaxable transaction within that five-year period under $\S 1374$. The five-year recognition period under $\S 1374(d)(7)$ was previously ten years but it was permanently shortened to five years under Public Law 114-113 for taxable years beginning after December 31, 2014. Consolidated Appropriations Act of 2016, Pub. L. No. 114-113, § 127, 129 Stat. 2149, 3054.

${ }^{76}$ I.R.C. $\S 1001$ (a).

${ }^{77} I d . \S 301(\mathrm{a})-(\mathrm{e})$.

${ }^{78}$ See supra Part I.B.
}

Pitt Tax Review | ISSN 1932-1821 (print) 1932-1996 (online) DOI 10.5195/taxreview.2018.80 | http://taxreview.law.pitt.edu 
whether the transaction is structured as an asset sale or a sale of interests because it should receive a step-up in basis in the assets, either as a result of an election under $\S 754$ or, if all interests are acquired, under the rationale of Revenue Ruling 99-6. ${ }^{79}$

In at least one circumstance, selling noncorporate partners may prefer a sale of partnership interests to a sale of partnership assets. If the partners have a long-term holding period in their partnership interests, but the partnership has a short-term holding period in some or all of its assets, a sale of the partnership interests may entitle the selling partners to treat the entire sale as qualifying for long-term capital gain treatment (except to the extent of any potential depreciation recapture), whereas a sale of assets would likely require that some amount of the total gain be treated as short-term capital gain. ${ }^{80}$ For an owner of a disregarded entity, the structuring of the transaction as a sale of assets or a sale of interests is not an issue for federal income tax purposes because all sales of interests in a disregarded entity are treated as a sale of the entity's assets. ${ }^{81}$

The foregoing discussion addresses the treatment of the sale of interests in an entity compared to the sale of the entity's assets from a tax perspective. Often, the structure of the transaction will be dictated by nontax factors. For example, buyers often prefer to acquire an entity's assets rather than its interests because the historic liabilities will generally be left with the entity and not inherited by the new owners in an asset sale. ${ }^{82}$ On the other side of the ledger, there is often an advantage to the buyer in acquiring the interests in a business entity, which acquisition would include all of the entity's contracts, goodwill, and title to its assets, because the buyer will usually not incur transfer taxes, approval requirements, or notice obligations. Many of these nontax business issues can be addressed within the representation and indemnity provisions of a well-drafted asset purchase agreement or entity interest purchase agreement. As a result, it is often the relative bargaining

\footnotetext{
${ }^{79}$ Revenue Ruling 99-6 treats the sale of all partnership interests to a single buyer as a sale of partnership interests for the selling partners and a purchase of partnership assets for the buyer. Rev. Rul. 99-6, 1999-1 C.B. 432.

${ }^{80}$ This long-term capital gain treatment is not entirely free from doubt. WILLIAM S. MCKEE ET AL., FEDERAL TAXATION OF PARTNERSHIPS AND PARTNERS 9 16.03[1] (4th ed. 2007).

${ }^{81}$ See Treas. Reg. § 301.7701-3(a) (as amended in 2006).

${ }^{82}$ See, e.g., I.R.C. $\S 368(\mathrm{a})(1)(\mathrm{B}) ;$ cf. id. $\S 368(\mathrm{a})(1)(\mathrm{C})$.
}

Pitt Tax Review | ISSN 1932-1821 (print) 1932-1996 (online) DOI 10.5195/taxreview.2018.80 | http://taxreview.law.pitt.edu 


\section{2 |Pittsburgh Tax Review | Vol. 162018}

position of the sellers and buyers that will determine the form of the transaction. At the outset of a business or an investment, it is important to consider the likely form that an exit will take when choosing the tax status of the entity, so that the owners do not find themselves in a position of having to reduce their expectations regarding the net consideration they will receive upon exit.

Another form of exit (or, more precisely, a variation on the abovedescribed transactions) is the use of a tax-deferred transaction. One of the traditional exit strategies for the owners of a new business is to have the business acquired by a larger, publicly traded corporation for its stock. If available, these transactions are often structured to take advantage of the taxdeferred reorganization provisions of the Code. Entities that are structured as tax law corporations ( $\mathrm{C}$ corporations or $\mathrm{S}$ corporations) are permissible parties to a reorganization under $\S 368(\mathrm{~b})$. Tax law partnerships and disregarded entities are not permitted the use of tax deferred corporate reorganization provisions. A conversion of a tax law partnership or disregarded entity to a tax law corporation ${ }^{83}$ before the sale of its interests by the owners is a possible consideration. There is a potential concern that such a conversion might not be respected under step transaction or substance-overform principles, particularly if the conversion occurs shortly before the sale. ${ }^{84}$

\section{Other Factors}

Many factors other than those discussed above ${ }^{85}$ are considered in the choice-of-entity analysis. The most relevant factors depend upon the specific transaction. Examples that this author has seen in practice include:

1. There is a common preference among investors, bankers, accountants, and some corporate lawyers to choose a state law corporation (with or without the $\mathrm{S}$ corporation election) as the business entity. Often, this preference is based on familiarity with the investment vehicle, comfort with applicable legal or accounting principles, or perception of common practices. The

${ }^{83}$ This can be accomplished by checking the box on Form 8832 or by a merger or conversion of the tax law partnership or disregarded entity into an automatic corporation.

${ }^{84}$ See Gregory v. Helvering, 293 U.S. 465, 470 (1935).

${ }^{85}$ See supra Parts I.B, I.C.

Pitt Tax Review | ISSN 1932-1821 (print) 1932-1996 (online) DOI 10.5195/taxreview.2018.80 | http://taxreview.law.pitt.edu 
advisor should be certain to review the decision with the investors in light of the short-term and long-term consequences of that choice, including those discussed in this article.

2. Angel investors and other venture capital funds will often insist upon corporate form because of the undesirability of a potential pass-through of income from a tax law partnership without cash for the investor to pay the tax. Sometimes, this issue can be addressed by a discussion of the benefits of one level of tax and loss flow-through combined with provisions within the operating agreement or limited partnership agreement that address tax distributions and special allocations.

3. Non-U.S. and tax-exempt investors will often insist upon the use of a $\mathrm{C}$ corporation in order to prevent their direct liability for U.S. income taxes on operating income. In many cases, however, a C corporation "blocker" entity to hold the interests beneficially owned by the non-U.S. or tax-exempt investor can address the issue for those investors concerned with adverse tax consequences of pass-through treatment while allowing the taxable U.S. investors to benefit from such treatment.

As suggested above, a large array of factors may be relevant to particular transactions, entities, and owners. Advisors should be diligent in eliciting from their clients a prioritized list of the factors that the client considers important to the activities and assets of the entity and the owner(s) to make sure that the structure chosen best suits those factors.

\section{E. The "Obvious" Choice}

An analysis of the factors discussed above ${ }^{86}$ will generally lead the adviser to one conclusion-in most situations, a tax law partnership or disregarded entity will result in more favorable tax treatment for the owners. This "obvious answer" is largely driven by the double tax potential of a tax law corporation. In simplified terms, using maximum rates and addressing only income taxes, the rate differential before the effective date of the TCJA

${ }^{86}$ See supra Parts I.B, I.C.

Pitt Tax Review | ISSN 1932-1821 (print) 1932-1996 (online) DOI 10.5195/taxreview.2018.80 | http://taxreview.law.pitt.edu 
was $8.4 \%$ (approximately $48 \%{ }^{87}$ for distributed income from a tax law corporation compared to $39.6 \%$ for a tax law partnership or disregarded entity at maximum rates) ${ }^{88}$ The resulting tax savings was a permanent benefit that could be kept by the owners of the entity. However, it is important to note that under the pre-TCJA law, there were other significant tax benefits attached to tax law partnership or disregarded entity form, including those discussed above. ${ }^{89}$

There were, however, numerous situations in which the obvious choice may not have been the correct choice. For instance, certain investors do not want pass-through treatment because of their own tax situations; for example, as mentioned above, foreign investors do not want to be subject to U.S. tax on operating income under $\S \S 871$ and 881 , and tax-exempt investors (such as retirement funds, college endowments, foundations, etc.) do not want to be subject to tax under the unrelated business income tax regime of $\S 511$. It is notable that foreign investors and tax-exempt investors constitute a significant portion of the institutional investor pool from which many businesses seek to solicit funding. Also as mentioned earlier, many venture funds decline to invest in pass-through entities for a variety of reasons, including comfort with the entity form, the potential of tax without cash, and adverse tax treatment of some of their investors (which are often tax-exempt entities and foreign investors).

Another prime reason often presented for avoiding partnership treatment is the associated tax reporting complexity for the owners. In a tax law corporation, the owners are not taxed until actual distributions are made. ${ }^{90}$ The owners of tax law corporations receive a Form 1099-DIV that reports their dividend, redemption, or liquidation income to them in a manner that has minimal impact on the rest of their federal income tax return. ${ }^{91}$ For state tax law purposes, the owner of a tax law corporation receiving

\footnotetext{
${ }^{87}$ This $48 \%$ is based on the maximum rates of tax for corporations and individuals, so that the combined tax rate would be $35 \%$ (entity level) plus $39.6 \%$ of the remaining $65 \%$ (shareholder level).

${ }^{88}$ See Tax Cuts and Jobs Act, Pub. L. No. 115-97, § 11002(c), 131 Stat. 2054, 2059-60 (2017) (codified at $\S 1(f)(2)(A)(i i)$ ).

${ }^{89}$ See supra Part I.B.

${ }^{90}$ I.R.C. $\S 301(\mathrm{c})$.

${ }^{91}$ See, e.g., Treas. Reg. § 1.671-4(b)(2)(iv), ex. 2 (as amended in 2006).
}

Pitt Tax Review | ISSN 1932-1821 (print) 1932-1996 (online) DOI 10.5195/taxreview.2018.80 | http://taxreview.law.pitt.edu 
distributions from the corporation is generally taxable only in the state of the owner's residence or principal place of business.

In contrast to this "simple" situation, a partner of a tax law partnership or the owner of a disregarded entity receives a Form 1065 Schedule K-1 that reports the partner's allocable income, whether or not the allocable income was actually distributed to the partner, for every tax year of the partnership in which the partner is an owner. Similarly, an owner of a disregarded entity reports the owner's income from the entity on the owner's return, typically using Form 1040 Schedule C, every year whether distributions are made or not. In both cases, the impact on the owner's federal income tax return is likely to be profound as each item and tax attribute of the entity's operations will flow through separately to the owner's return. The Schedule K-1, perhaps revised for state-specific items, will also have a comparable effect on the owner's state income tax return. Moreover, to the extent that the business operates in more than one jurisdiction or the owner and the business file their returns in different jurisdictions, the owner will likely have to file returns in multiple states, or the entity will have to agree to file composite returns on behalf of its owners in states, other than the owner's home jurisdiction, that permit the filing of such composite tax returns.

Other benefits associated with adopting the corporate form occur upon disposition of the equity interests in the entity. In addition to the availability of long-term capital gain treatment upon the disposition of ownership interests in tax law corporations, ${ }^{92}$ discussed above,${ }^{93}$ the sale of certain small business stock of a tax law corporation may qualify for a $50 \%$, a $75 \%$, or a $100 \%$ exclusion from income under $\S 1202$ (a). In order to obtain the benefit of this exemption, numerous requirements must be satisfied by the corporation and the selling shareholder including a five-year holding period for the stock, C corporation status, active trade or business tests, specific acquisition dates to qualify for the different exclusion percentages, per issuer limitations, original issuance, and so on. ${ }^{94}$

${ }^{92}$ I.R.C. $\S \S 1374(c)(1), 1375(b)(2)-(4)$ (imposing entity-level taxes upon S corporations that were formerly C corporations).

${ }^{93}$ See supra Part I.C.

${ }^{94}$ See I.R.C. § 1202(a)(1).

Pitt Tax Review | ISSN 1932-1821 (print) 1932-1996 (online) DOI 10.5195/taxreview.2018.80 | http://taxreview.law.pitt.edu 


\section{6 | Pittsburgh Tax Review | Vol. 162018}

\section{SUMMARY OF THE RELEVANT PROVISIONS OF THE TCJA}

Many changes were made to the Code by the TCJA, but only the changes deemed relevant to the choice-of-entity discussion are discussed here.

\section{A. Corporate Tax Law Changes}

\section{Corporate Tax Rates}

In 2017, prior to the effective date of the TCJA, corporations were subject to federal income tax at graduated rates to a maximum of $35 \%$ for income in excess of $\$ 10,000,000 .{ }^{95}$ In that year, corporations were taxed at a marginal rate of $34 \%$ for corporations with taxable income in excess of $\$ 75,000 .^{96}$ The benefits of the lower rate brackets were eliminated by additional surtaxes, so that corporations with taxable income in excess of $\$ 15,000,000$ were effectively subject to a $35 \%$ flat rate. ${ }^{97}$

Under the TCJA, corporations are now subject to a flat rate of $21 \%{ }^{98}$ Certain conforming changes to the Code were made as a result of the adoption of a lower single rate of corporate taxation, including changes to the

\footnotetext{
${ }^{95} I d$. $~ 11(\mathrm{~b})(2017)$.

${ }^{96}$ See id. $\S 11(\mathrm{~b})(1)(\mathrm{C})$.

${ }^{97}$ See id. $\S 11(\mathrm{~b})(1)$.

${ }^{98} I d . \S 11(\mathrm{~b})$.
}

Pitt Tax Review | ISSN 1932-1821 (print) 1932-1996 (online) DOI 10.5195/taxreview.2018.80 | http://taxreview.law.pitt.edu 
tax on personal service corporations, ${ }^{99}$ the dividends received deduction, ${ }^{100}$ and the maximum tax rate for corporate capital gains. ${ }^{101}$

\section{Corporate Alternative Minimum Tax Repeal}

Under the TCJA, the alternative minimum tax (AMT) for corporations was repealed for tax years beginning after 2017. ${ }^{102}$ In addition, any unused minimum tax credit of a corporation may be used to offset regular tax liability for any tax year, and a portion of any unused minimum tax credit is refundable in the 2018 through 2021 tax years. ${ }^{103}$ As discussed below, the AMT treatment of individuals was not nearly as favorable. ${ }^{104}$

${ }^{99}$ Tax Cuts and Jobs Act, Pub. L. No. 115-97, § 13001(b), 131 Stat. 2054, 2096-98 (2017) (codified at $\S 11(\mathrm{~b}))$. Section 11(b), prior to the enactment of the TCJA, provided that the amount of tax on the taxable income of a qualified personal service corporation was equal to $35 \%$ of the taxable income and not the graduated rates of tax applicable to other corporations. I.R.C. §11(b). This provision was eliminated in the TCJA, because personal service corporations are now subject to the same rate of tax as other corporations - a flat $21 \%$. Id.

${ }^{100}$ Tax Cuts and Jobs Act $\S 13002(a)(1), 131$ Stat. at 2100 (codified at $\S 243(a)(1)$ ). Under the TCJA, the percentage of the dividends received deduction allowed for all qualified dividends was reduced from $70 \%$ to $50 \%$, and the percentage for qualified dividends from a more than $20 \%$ owned corporation was reduced from $80 \%$ to $65 \%$. Id. § 13002(a)(1)-(2)(A), 131 Stat. at 2100 (codified at $\S 243(\mathrm{a})(1)$ ). These changes reflect the reduction in the corporate tax rate to $21 \%$ and the deductions retain approximately the same economic impact before and after the TCJA. See Hitt \& Eicher, supra note 5, at 34 (providing a more detailed discussion of how the TCJA's changes are reflected in the new corporate tax rate). Also, the $100 \%$ dividends received deduction for dividends among members of the same affiliated group (as defined in § 1504(a)) remains intact. Id.; see I.R.C. § 243(b)(2)-(3).

${ }^{101}$ Tax Cuts and Jobs Act $\S 13001(a)$, (b)(2)(A), 131 Stat. at 2096-97 (codified at $\left.\S 11(b)\right)$. The limitation on the maximum rate on capital gains to $35 \%$ was repealed as unnecessary. Hitt \& Eicher, supra note 5 , at 34 .

\footnotetext{
${ }^{102}$ Tax Cuts and Jobs Act $\S 12001$ (a), 131 Stat. at 2092 (codified at $\S 55(a)$ ).

${ }^{103} I d . \S 12002(a), 131$ Stat. at 2094 (codified at § 53(e)(1)-(2)).

${ }^{104}$ See infra Part II.B.4.
}

Pitt Tax Review | ISSN 1932-1821 (print) 1932-1996 (online) DOI 10.5195/taxreview.2018.80 | http://taxreview.law.pitt.edu 


\section{Pittsburgh Tax Review | Vol. 162018}

\section{B. Individual Tax Law Changes ${ }^{105}$}

\section{Individual Tax Rates}

There were relatively minor changes made to the individual income tax rates under $\S 1(\mathrm{a})-(\mathrm{d}) .{ }^{106}$ The graduated rate structure was retained, although the rates were slightly decreased above the initial bracket and the brackets were extended slightly. ${ }^{107}$ The maximum rate of individual income tax decreased from $39.6 \%$ to $37 \% .{ }^{108}$ The TCJA also generally retains the maximum rate on net capital gains and qualified dividends at $20 \%$, with lower rates of $0 \%$ and $15 \%$ applying to certain thresholds of capital gains and taxable income. ${ }^{109}$ However, the brackets for increasing the rate of capital gain taxes from $0 \%$ to $15 \%$ and from $15 \%$ to $20 \%$ are no longer linked to the brackets applicable to ordinary income. ${ }^{110}$

\section{Pass-Through Business Deduction}

Prior to the enactment of the TCJA, there were no rate reductions or (equivalent exemptions) for pass-through business income. ${ }^{11}$ Instead, business income of pass-through entities was generally taxed at the applicable rates of the business's owner(s). ${ }^{112}$

For tax years beginning after December 31, 2017 (and before January 1, 2026), [a non-corporate] taxpayer may generally deduct 20-percent of the "qualified business income" [the taxpayer] reports from a partnership, S corporation, or sole proprietorship, as well as 20-percent of aggregate qualified dividends [from a]

\footnotetext{
${ }^{105}$ The law changes in this part are described as relating to individuals but they apply equally to other noncorporate taxpayers, such as trusts and estates. See generally Hitt \& Eicher, supra note 5, at 3438 (elaborating on law changes for noncorporate taxpayers).

${ }^{106}$ See Hitt \& Eicher, supra note 5, at 35.

${ }^{107}$ Tax Cuts and Jobs Act $\S 11001$ (a), 131 Stat. at 2054-56 (codified at $\S 1(j)(2)$ ).

${ }^{108}$ See id. § 11001(a), 131 Stat. at 2054-56 (codified at $\left.\S 1(j)(2)(A)-(D)\right)$.

${ }^{109} I d$. (codified at $\left.\S 1(\mathrm{~h})(1)\right)$.

${ }^{110} I d$. (codified at $\left.\S 1(\mathrm{~h})(1)(\mathrm{A})-(\mathrm{E})\right)$.

${ }^{111}$ See Hitt \& Eicher, supra note 5, at 36.

${ }^{112} \mathrm{Id}$.
}

Pitt Tax Review | ISSN 1932-1821 (print) 1932-1996 (online) DOI 10.5195/taxreview.2018.80 | http://taxreview.law.pitt.edu 
REIT, ${ }^{113}$ qualified cooperative dividends, ${ }^{114}$ and qualified publicly traded partnership income. ${ }^{115}$

The actual amount that a taxpayer may claim as a deduction under $\S 199$ A with respect to any qualified trade or business is limited to the lesser of:

(A) 20-percent of the taxpayer's qualified business income with respect to the qualified trade or business, or (B) the greater of (i) 50-percent of the $\mathrm{W}-2$ wages with respect to the qualified trade or business, or (ii) the sum of 25 -percent of the W-2 wages with respect to the qualified trade or business, plus 2.5-percent of the unadjusted basis immediately after acquisition of all qualified property. ${ }^{116}$

Qualified property means, generally, "tangible property ... subject to the allowance for depreciation under $\S 167 . " 117$ This limit, however, does not apply until the taxpayer's taxable income reaches the threshold amount described below. ${ }^{118}$ In addition to the wage-based limitation, there is an overall limitation on the $\S 199 \mathrm{~A}$ deduction equal to the lesser of (1) the "combined qualified business income amount" or (2) an amount equal to $20 \%$ of the taxpayer's taxable income (reduced by any net capital gain). ${ }^{119}$ "The combined qualified business income amount is the sum of the deductions for qualified trades or businesses determined for each qualified trade or business plus 20-percent of qualified REIT dividends and qualified cooperative dividends received by the taxpayer for the taxable year."

Qualified business income is determined on the basis of each "qualified trade or business of the taxpayer," subject to potential aggregation of certain

${ }^{113}$ A real estate investment trust (REIT) is taxable under $\S \S 856(a), 857(a)-(b)$.

${ }^{114}$ I.R.C. § 199A(e)(4) (defining qualified cooperative dividends to include certain amounts received from or allocated by an organization or corporation described in $\$ 501(\mathrm{c})(12), \S 1381(\mathrm{a})$, or an organization which is governed under the rules applicable to cooperatives under $\S 1388(\mathrm{a})$, (c), and (f)).

${ }^{115}$ Hitt \& Eicher, supra note 5, at 36 (certain income and gain from publicly traded partnerships under $\S 7704(\mathrm{~d}))$.

${ }^{116}$ I.R.C. $\S 199 \mathrm{~A}(\mathrm{~b})(2)(\mathrm{A})-(\mathrm{B})$.

${ }^{117} I d . \S 199 \mathrm{~A}(\mathrm{~b})(6)(\mathrm{A})$.

${ }^{118} I d . \S 199 \mathrm{~A}(\mathrm{~b})(3)(\mathrm{A})$.

${ }^{119}$ Id. $\S 199 \mathrm{~A}(\mathrm{a})$.

${ }^{120}$ Id. § 199A(b)(1); see Hitt \& Eicher, supra note 5, at 37 (providing a quantitative discussion with examples of the operation of this limitation and the operation of $\S 199 \mathrm{~A}$ more generally).

Pitt Tax Review | ISSN 1932-1821 (print) 1932-1996 (online) DOI 10.5195/taxreview.2018.80 | http://taxreview.law.pitt.edu 
trades or businesses, as discussed below. ${ }^{121}$ Qualified trade or business income must be sourced from a "business [conducted] within the United States." ${ }^{122}$ Investment-related income, deductions, gains, and losses are excluded from the computation of qualified business income. ${ }^{123}$

For purposes of choice-of-entity analysis, there is an important exclusion from the definition of qualified business income for income from certain "specified service trades or businesses." ${ }^{124}$ Specified service trades or businesses are trades or businesses described in $\S 1202(\mathrm{e})(3)(\mathrm{A})$ (subject to certain exceptions), as well as services consisting of investing and investment management, trading, or dealing in securities, partnership interests, or commodities. ${ }^{125}$ Section 1202(e)(3)(A) specifies:

[A]ny trade or business involving the performance of services in the fields of health, law, engineering, architecture, accounting, actuarial science, performing arts, consulting, athletics, financial services, brokerage services, or any trade or business where the principal asset of such trade or business is the reputation or skill of [one] or more of its employees. ${ }^{126}$

For purposes of the definition of specified service trades or business in $\S 199 \mathrm{~A}(\mathrm{~d})$, trades or businesses involving engineering and architecture are excluded from the list of trade or businesses from $\S 1202(\mathrm{e})(3)(\mathrm{A})$. Additionally, excluded from the definition of qualified business income is income from a "trade or business of performing services as an employee." 127

The wage and property limitation of $\S 199 \mathrm{~A}(\mathrm{~b})(2)$ and the exclusion of specified service trades or businesses from the definition of qualified

\footnotetext{
${ }^{121}$ See I.R.C. § 199A(c)(1).

${ }^{122} I d . \S 199 \mathrm{~A}(\mathrm{c})(3)(\mathrm{A})(\mathrm{i})$.

${ }^{123} \mathrm{Id}$. § 199A(c)(3)(B).

${ }^{124} I d . \S 199 \mathrm{~A}(\mathrm{~d})(1)-(2)$.

${ }^{125} I d . \S \S 199 \mathrm{~A}(\mathrm{~d})(2)(\mathrm{B}), 1202(\mathrm{e})(3)(\mathrm{A})$.

${ }^{126}$ Id. § 1202(e)(3)(A); see Qualified Business Income Deduction, Prop. Treas. Reg. § 1.199A5(b), 2018-35 I.R.B. 353, 369-70 (indicating in the preamble explaining the proposed regulation that additional exclusions from the definition of specified service trades or businesses include, notably, banking, real estate brokers, and insurance agent brokers).

${ }^{127} I d . \S 199 \mathrm{~A}(\mathrm{~d})(1)(\mathrm{B})$.
}

Pitt Tax Review | ISSN 1932-1821 (print) 1932-1996 (online) DOI 10.5195/taxreview.2018.80 | http://taxreview.law.pitt.edu 
business income of $\S 199 \mathrm{~A}(\mathrm{~d})(1)(\mathrm{A})^{128}$ do not apply until a taxpayer's taxable income reaches a threshold amount. ${ }^{129}$ The threshold amount for 2018 is $\$ 157,500$ ( $\$ 315,000$ for a married couple filing jointly), which is to be indexed for inflation for taxable years after 2018 and is subject to a phaseout for income over those threshold amounts. ${ }^{130}$

On August 8, 2018, the Treasury Department released proposed regulations under $\S 199 \mathrm{~A} .{ }^{131}$ The proposed computational and definitional rules under $\S 199 \mathrm{~A}$ have a prospective effective date, meaning that they are proposed to be effective for tax years ending after final regulations are published in the Federal Register. ${ }^{132}$ However, the preamble to the proposed regulations states that taxpayers may rely on the proposed regulations until the final regulations are effective. ${ }^{133}$ In addition, the $\S 199 \mathrm{~A}$ antiabuse rules in the regulations are proposed to apply to tax years ending after December 22, 2017, the date of enactment of the TCJA. ${ }^{134}$

There are a number of helpful nuggets of guidance within the proposed $\S 199$ A regulations. For instance, when an operating business rents real estate from a related entity (so called self-rentals), the real estate entity is treated as part of the operating business, as long as the operating business and real estate entity are under common control and the real estate is used in the operating trade or business. ${ }^{135}$ Similarly, the proposed regulations allow businesses under common control to aggregate W-2 wages if the wage expense is allocated to each of the businesses, and wages paid by certain

${ }^{128}$ Id. § 199A(b)(1)(A), (3)(A) (noting that employee services income is always excluded from the definition of qualified business income even if the taxpayer's income is below the threshold amount).

${ }^{129} I d . \S 199 \mathrm{~A}(\mathrm{~b})(3)(\mathrm{A}),(\mathrm{d})(3)(\mathrm{A})$.

${ }^{130} I d . \S 199 \mathrm{~A}(\mathrm{e})(2)(\mathrm{A})-(\mathrm{B})$.

${ }^{131}$ Press Release, U.S. Dep't of Treasury, Treasury Issues Proposed Regulations on New 20 Percent Deduction for Pass-Through Businesses (Aug. 8, 2018), https://home.treasury.gov/news/press-releases/ $\operatorname{sm} 456$.

${ }^{132}$ Qualified Business Income Deduction, 2018-35 I.R.B. 353, 375 (the portion of the preamble that discusses the effective date of the proposed regulations).

${ }^{133} I d$.

${ }^{134} \mathrm{Id}$. 384

${ }^{135}$ Qualified Business Income Deduction, Prop. Treas. Reg. § 1.199A-1(b)(13), 2018-35 I.R.B. at

Pitt Tax Review | ISSN 1932-1821 (print) 1932-1996 (online) DOI 10.5195/taxreview.2018.80 | http://taxreview.law.pitt.edu 
third-party payors (such as professional employer organizations) count towards the W-2 wage limitation, so long as the wages are paid on behalf of the operating business. ${ }^{136}$ The proposed regulations would also permit the aggregation of certain business activities in determining the $\S 199 \mathrm{~A}$ deduction. ${ }^{137}$ In order to be aggregated, none of the combined businesses may be a specified service trade or business, the business must be commonly owned, and a functional integration test must be met. ${ }^{138}$

Under the proposed regulations, the Treasury Department and the IRS interpreted the catchall category for specified service trades or businesses under $\S 199 \mathrm{~A}$ (d) (i.e., "any trade or business where the principal asset of such trade or business is the reputation or skill of one or more of its employees") very narrowly. ${ }^{139}$ Only the following categories of businesses are to be included within the definition of specified service trades or businesses under the catchall category: (1) receiving income for endorsing products or services; (2) licensing or receiving income for the use of an individual's image, likeness, or trademark; and (3) receiving appearance fees. ${ }^{140}$

Finally, the proposed regulations have general antiabuse provisions as well as provisions targeted at certain identified abuses. ${ }^{141}$ One proposed idea challenged by the proposed regulations is the "crack and pack" strategy, which is designed to allow a specified service trade or business to "crack" open its business by isolating certain administrative functions and then "pack" those functions into a supposedly separate trade or business that would not otherwise be a specified service trade or business. The proposed regulations address this planning idea by providing that when a specified service trade or business has common ownership with a related business, the income generated by that related business for services or property provided 395.

${ }^{136}$ Id. § 1.199A-2(b)(2)(i)-(ii), 2018-35 I.R.B. at 389-90; id. § 1.199A-4(b)(2), 2018-35 I.R.B. at

${ }^{137}$ Id. § 1.199A-4(b), 2018-35 I.R.B. at 394.

${ }^{138}$ Id. § 1.199A-4(b)(i), (iv)-(v), 2018-35 I.R.B. at 394-95.

${ }^{139}$ See I.R.C. $\S \S 199 A(d)(2), 1202(e)(3)(A) ;$ see also Qualified Business Income Deduction, Prop. Treas. Reg. § 1.199A-5(b)(2)(xiv), 2018-35 I.R.B. at 399.

${ }^{140}$ Qualified Business Income Deduction, Prop. Treas. Reg. § 1.199A-5(b)(2)(xiv)(A)-(C), 201835 I.R.B. $343,399$.

${ }^{141} I d$. 1.199 A-2(c)(1)(iv), 2018-35 I.R.B. at 391; id. § 1.199A-6(d)(3)(v), 2018-35 I.R.B. at 403.

Pitt Tax Review | ISSN 1932-1821 (print) 1932-1996 (online) DOI 10.5195/taxreview.2018.80 | http://taxreview.law.pitt.edu 
to the specified service trade or business will be treated as income from that specified service trade or business. ${ }^{142}$ Another idea promoted by some planners was to use multiple trusts to circumvent the various $\S 199 \mathrm{~A}$ threshold limitations. The proposed regulations provide that in these types of situations, the various trusts will be treated as a single trust for purposes of applying the various $\S 199 \mathrm{~A}$ limitations, unless there are significant nontax (or non-income tax) purposes for using multiple trusts. ${ }^{143}$

\section{Profits Interest/Carried Interest Rule}

Under $\S 1061(a)(2)$, as amended by the TCJA, a taxpayer who holds an "applicable partnership interest" will recognize net long-term capital gain with respect to such interest only after the taxpayer has held the interest for at least three years. ${ }^{144}$ If the three-year holding period ${ }^{145}$ requirement is not met, the taxpayer's net long-term capital gain will be treated as a short-term capital gain, notwithstanding $\S 83 .{ }^{146}$ It should be noted that short-term capital gains are potentially subject to tax at federal ordinary income rates up to a maximum of $37 \%$. The three-year holding period rule applies to capital gains recognized with respect to an applicable partnership interest after 2017, regardless of when the taxpayer acquired the interest. ${ }^{147}$

Section 1061(c)(1) defines an "applicable partnership interest [to] mean[,] any interest in a partnership which, directly or indirectly, is transferred to (or is held by) the taxpayer in connection with the performance of substantial services by the taxpayer, or any other related person, in any applicable trade or business." 148 An interest held by a person "who is employed by another entity that is conducting a trade or business (other than an applicable trade or business) and only provides services to such other

${ }^{142} I d . \S 1.199 \mathrm{~A}-5(\mathrm{c})(2)-(3), 2018-35$ I.R.B. at 400.

${ }^{143} I d$. $1.199 \mathrm{~A}-6(\mathrm{~d})(3)(\mathrm{v}), 2018-35$ I.R.B. at 403.

${ }^{144}$ I.R.C. $\S 1061(\mathrm{a})(2)$.

${ }^{145}$ The normal holding period required for long-term capital gain treatment is more than one year. Id. $\S 1222$.

${ }^{146} I d . \S 1061$ (a).

${ }^{147}$ See id. § 1061(a)(2); see also id. § 1061(c)(1).

${ }^{148} I d . \S 1061(\mathrm{c})(1)$.

Pitt Tax Review | ISSN 1932-1821 (print) 1932-1996 (online) DOI 10.5195/taxreview.2018.80 | http://taxreview.law.pitt.edu 


\section{4 | Pittsburgh Tax Review | Vol. 162018}

entity" is excluded. ${ }^{149}$ Section 1061(c)(2) defines the term applicable trade or business to mean:

[A]ny activity conducted on a regular, continuous and substantial basis which, regardless of whether the activity is conducted in one or more entities, consists, in whole or in part, of (1) raising or returning capital, and (2) either (i) investing in (or disposing of) specified assets (or identifying specified assets for investing or disposition), or (ii) developing specified assets. ${ }^{150}$

For purposes of the carried interest rule, the term specified assets means securities, ${ }^{151}$ commodities, ${ }^{152}$ rental or investment real estate, cash or cash equivalents, options or derivative contracts, or a partnership interest "to the extent of the partnership's proportionate interest in any of the foregoing" assets. ${ }^{153}$ The carried interest rules exclude certain partnerships from the definition of an applicable partnership interest. ${ }^{154}$ Thus, an applicable partnership interest does not include any partnership interest that is held by a corporation. ${ }^{155}$ In March 2018, the IRS issued Notice 2018-18, which announced that future regulations will clarify that the term "corporation" does not include an S corporation when used in $\S 1061$. $^{156}$ In addition, an applicable partnership interest does not include a partnership interest in which a taxpayer owns a capital interest in the partnership that permits "the taxpayer to share in partnership capital commensurate with" (1) the amount of capital contributed, or (2) the value of such interest that was subject to tax under $\S 83$ upon issuance or vesting. ${ }^{157}$

Section 1061(d) provides an aggregate approach in the event of the sale of an applicable partnership interest to a related person. ${ }^{158}$ If a taxpayer

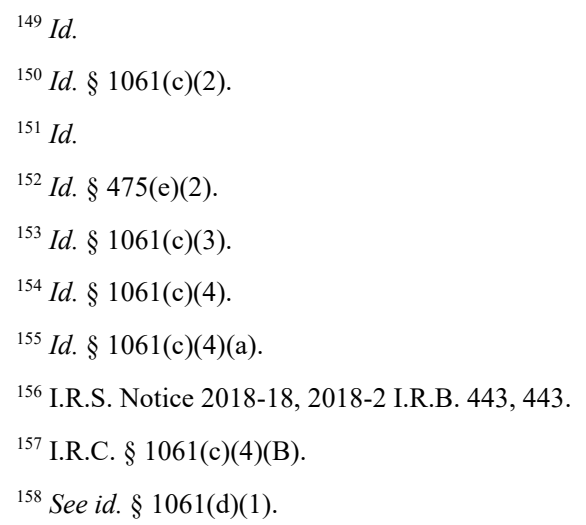

Pitt Tax Review | ISSN 1932-1821 (print) 1932-1996 (online) DOI 10.5195/taxreview.2018.80 | http://taxreview.law.pitt.edu 
transfers an applicable partnership interest to a related person (as defined below), "the taxpayer [is required to include] in gross income (as short-term capital gain) the excess (if any) of (A) ... the taxpayer's [net] long-term capital gains" attributable to the sale of an asset "held not more than [three] years as is allocable to the interest; over... (B) any amount [that would otherwise have been] treated as a short-term capital gain ... with respect to the transfer of [the] interest." "159 The term related party means a person related to the taxpayer if: "(a) [such] person is a member of the taxpayer's family within the meaning of $[\S] 318(\mathrm{a})(1)$, or (b) [such] person performed a service within the current calendar year or the preceding three calendar years in any applicable trade or business in which or for which the taxpayer performed a service." 160

\section{Individual Alternative Minimum Tax}

While the corporate AMT was repealed by the TCJA, as described above, ${ }^{161}$ the individual AMT was retained with certain generally favorable modifications. ${ }^{162}$ The new law increases the AMT exemption amount from $\$ 84,500$ in 2017 to $\$ 109,400$ in 2018 for married taxpayers filing a joint return and from $\$ 54,300$ in 2017 to $\$ 70,300$ in 2018 for single taxpayers. ${ }^{163}$ These exemptions are subject to phase out as a taxpayer's alternative minimum taxable income (AMTI) exceeds certain thresholds. ${ }^{164}$ In 2017, these thresholds were $\$ 160,900$ for married taxpayers filing jointly and $\$ 120,700$ for single taxpayers. ${ }^{165}$ Under the TCJA, these phase-out thresholds were significantly increased to $\$ 1,000,000$ for married taxpayers filing jointly and $\$ 500,000$ for single taxpayers. ${ }^{166}$

\footnotetext{
${ }^{159} I d$.

${ }^{160} I d . \S 1061(\mathrm{~d})(2)$.

${ }^{161}$ See supra Part II.A.2.

${ }^{162}$ See I.R.C. § 55; see also Tax Cuts and Jobs Act, Pub. L. No. 115-97, § 12001(b), 131 Stat. 2054, 2092-94 (2017) (codified at § 55(a)-(d)).

${ }^{163}$ I.R.C. $\S 55(\mathrm{~d})(1),(4)(\mathrm{A})(\mathrm{i})$.

${ }^{164} I d . \S 55(\mathrm{~d})(2),(4)(\mathrm{A})(\mathrm{ii})$.

${ }^{165} I d . \S 55(\mathrm{~d})(2)$.

${ }^{166} I d . \S 55(\mathrm{~d})(4)(\mathrm{A})(\mathrm{ii})$.
}

Pitt Tax Review | ISSN 1932-1821 (print) 1932-1996 (online) DOI 10.5195/taxreview.2018.80 | http://taxreview.law.pitt.edu 


\section{Loss Limitation Rules}

In addition to the panoply of restrictions applicable to noncorporate taxpayers claiming losses from business and investment activities, ${ }^{167}$ a new provision in the Code further limits a taxpayer's ability to deduct certain "excess" business losses. ${ }^{168}$ Excess business losses of taxpayers, other than corporations, are not allowed in the current tax year but must be carried forward as part of the taxpayer's net operating loss (NOL) carry forward. ${ }^{169}$ NOL carryovers are generally allowed for a taxable year up to the lesser of the carryover amount or $80 \%$ of taxable income determined without regard to the NOL deduction. ${ }^{170}$

An excess business loss subject to the limitation under $\S 461(l)(3)(\mathrm{A})$ is the excess of business deductions over business income plus a threshold amount of $\$ 250,000$ ( $\$ 500,000$ for a married couple filing jointly). This threshold amount is to be indexed for inflation in future years. ${ }^{171}$ Thus, in effect, this provision allows business losses realized in a taxable year to offset business income and up to $\$ 250,000$ (or $\$ 500,000$ ) of other income with any "excess" loss added to the taxpayer's NOL carry forward. ${ }^{172}$ This provision applies after application of the passive loss rules of $\S 469 .{ }^{173}$

\section{CHOICE-OF-ENTITY ANALYSIS AFTER THE TCJA}

After absorbing the changes to the taxation of different forms of ownership, the questions most relevant to the choice-of-entity analysis are where are we now and how have things changed? As described above, our old wisdom was that the most favorable tax treatment generally resulted from

\footnotetext{
${ }^{167}$ See id. $\S \S 465,469$ (limiting losses to amounts at risk and limiting passive activity losses, respectively).

${ }^{168} I d . \S 461(1)$.

${ }^{169} I d . \S 461(1)(1)-(2)$.

${ }^{170} I d$. $\S \S 172(a), 461(1)(2)$. Section 172 was amended by the TCJA to add the $80 \%$ of taxable income limitation. Tax Cuts and Jobs Act, Pub. L. No. 115-97, § 13302(a)(1), 131 Stat. 2054, 2121 (2017) (codified at $\S 172(a)$ ).

${ }^{171}$ I.R.C. $\S 461(1)(3)(B)$.

${ }^{172}$ See id. $\S 461(1)(1)-(3)$.

${ }^{173}$ Id. § 461(1)(6).
}

Pitt Tax Review | ISSN 1932-1821 (print) 1932-1996 (online) DOI 10.5195/taxreview.2018.80 | http://taxreview.law.pitt.edu 
adoption of an entity form that permitted pass-through or disregarded status taxation. Thus, in a properly run universe where tax rules the world, we would have been recommending partnerships and LLCs. For business and investment arrangements in which nontax factors suggested the use of a tax law corporation and where the stock ownership and class of stock requirements of $\S 1362$ were satisfied, we would consider S corporations as an alternative, particularly when trying to manage employment taxes ${ }^{174}$ or planning for an eventual exit by means of a tax-deferred corporate reorganization. ${ }^{175}$

In the brave new world of post-TCJA taxation, many of the same principles continue to apply. There is often still a rate benefit for pass-through taxation but the gap between double-tax and single-tax environments has narrowed substantially or, in some cases, been entirely eliminated. Prior to the TCJA, the income tax rate differential at maximum rates was $8.4 \%$ in favor of pass-through taxation $\left(48 \%\right.$ for distributed corporate income ${ }^{176}$ compared to $39.6 \%$ for single-level individual tax). ${ }^{177}$ After the TCJA, the rate differential will depend upon whether the entity's income qualifies for the pass-through deduction. ${ }^{178}$ If the pass-through deduction of $20 \%$ is fully available, the rate differential would be $7.2 \%$ in favor of pass-through taxation $(36.8 \%$ for distributed corporate income compared to $29.6 \%$ for single level individual taxation, net of the pass-through deduction). ${ }^{179}$ If the pass-through deduction of $20 \%$ is entirely unavailable, the rate differential would be $0.2 \%$ in favor of corporate taxation $(36.8 \%$ for distributed corporate

\footnotetext{
${ }^{174} \mathrm{~S}$ corporations permit the owners to effectively manage their FICA or SECA taxes by paying both salaries (subject to employment taxes) and dividends (not subject to employment taxes), as long as at least "reasonable compensation" is paid, as discussed above. See id. § 1362(a)-(b); see also Ding v. Comm'r, 74 T.C.M. (CCH) 708, 1997 T.C.M. (RIA) ๆ 97,435 (1997), aff'd, 200 F.3d 587 (9th Cir. 1999).

${ }^{175}$ See generally I.R.C. § 368(a)(1)(A)-(D).

${ }^{176}$ See id. § 1(h)(1)(D), (h)(11); see also id. § 11(b). A corporate-level tax of 35\% combined with a shareholder-level tax of $20 \%$ of the remaining $65 \%$ generates a $13 \%$ double tax under pre-TCJA taxation. Id. § 11(b); Tax Cuts and Jobs Act, Pub. L. No. 115-97, § 13001(b), 131 Stat. 2054, 2096-98 (2017) (codified at $\S 11(b)$ ).

177 See Hitt \& Eicher, supra note 5, at 40 (providing a more complete discussion of this rate differential, including the impact of other taxes).

${ }^{178}$ I.R.C. § 1(h); see id. § 199A.

${ }^{179}$ See id. $\S 1(\mathrm{~h})(1)(\mathrm{D})$.
}

Pitt Tax Review | ISSN 1932-1821 (print) 1932-1996 (online) DOI 10.5195/taxreview.2018.80 | http://taxreview.law.pitt.edu 
income compared to $37 \%$ for single-level individual taxation, without the pass-through deduction). ${ }^{180}$

Accordingly, for businesses that do not qualify for the pass-through deduction, including specified service trades or businesses and businesses with insufficient W-2 wages or capital assets to qualify for the full benefit of the deduction after exceeding the income threshold, there is almost no difference between adopting a corporate structure and a pass-through structure based on a straight comparison of rates. For businesses that qualify for the pass-through deduction in whole or in part, the differential has decreased somewhat compared to the rate differential prior to the TCJA, so that the choice of entity analysis may look with increasing favor towards the nontax factors mentioned above.

The discussion of rate differential above assumes an immediate distribution of corporate earnings so that in the corporate double-taxation environment the individual rate on distributed income is applied at approximately the same time as the corporate rate. However, in many scenarios, the tax law corporation may be able to retain its income for a significant period of time. The longer that the corporation can refrain from making taxable distributions, the more that the initial tax differential $(21 \%$ corporate tax rate compared to $37 \%$ individual tax rate) can generate a timevalue-of-money benefit for the entity's owners. At a certain point, the timevalue benefit of an initially lower rate will eliminate the higher tax rate associated with the current double-taxation regime. ${ }^{181}$

In the event that the shareholders need or want access to the earnings of the corporation, loans to shareholders may be a technique to continue the deferral, except that the general nondeductibility of personal interest will reduce some of the deferral benefit. One possibility for continuing the benefit of the initial rate differential is for the shareholder to hold the corporate stock until death in order to obtain a step-up in basis under $\S 1014$. Section 1014(a)(1) would allow the stockholder's heirs to dispose of the shares without generating tax on the retained income, particularly in light of the significantly increased estate tax exemption under $\S 2010(\mathrm{c}) .{ }^{182}$ It should be

\footnotetext{
${ }^{180}$ See id. $\S 1(\mathrm{~h})(1)(\mathrm{B})$.

181 The time benefit of a corporation holding income for twenty years in the current rate environment should compensate for the rate differential depending upon the discount rate that is applied.

${ }^{182}$ See I.R.C. § 1014(a); see also id. § 2010(c).
}

Pitt Tax Review | ISSN 1932-1821 (print) 1932-1996 (online) DOI 10.5195/taxreview.2018.80 | http://taxreview.law.pitt.edu 
noted that a potential buyer of a business with retained $\mathrm{C}$ corporation income may pay less for the stock of the target corporation in light of the potential for dividend taxation when earnings are distributed by the corporation, but it still may result in a net tax benefit, particularly for a buyer that is a corporation.

There are some provisions that may affect the choice-of-entity analysis for taxpayers in special circumstances. For instance, it would likely be preferable to hold a business or investment that generates significant tax preference items in a $\mathrm{C}$ corporation rather than a pass-through entity, given the repeal of the alternative minimum tax rules for corporations and the retention of the comparable individual alternative minimum tax rules under $\S 55,{ }^{183}$ even with an increased exemption and threshold for exemption phase-out. Also, due to certain restrictions on the utilization of the losses of individuals discussed above, ${ }^{184}$ it may be beneficial to utilize a corporation, which is subject to far fewer restrictions, when considering a business that either projects start-up period losses or fluctuating levels of income and loss.

There are some continuing benefits to utilizing a pass-through entity notwithstanding a narrowing or elimination of the rate differential. Among those benefits, discussed in more detail above, ${ }^{185}$ are flexibility in allocation, ease of moving assets in and out of the entity, the ability to include entitylevel debt in the investor's basis for the purposes of distributions and loss allocations, and the availability of profits interests as a compensation device (though now subject to a three-year holding period for long-term capital gain treatment under $\S 1061) .{ }^{186}$

One of the most difficult factors to evaluate is the potential for law change. The risk in adopting corporate form as opposed to the more traditional choice of a pass-through entity may be larger for two reasons. First, the current regime of a significantly reduced corporate rate of tax is new. New provisions are inherently more subject to change than provisions that have a longer and more established history. The second and perhaps more significant risk in adopting corporate form is the "lock-in" effect. As

\footnotetext{
${ }^{183} I d . \S 55(\mathrm{a}),(\mathrm{b}),(\mathrm{d})(4)$.

${ }^{184}$ See supra Part II.B.5.

${ }^{185}$ See supra Part I.B.

${ }^{186}$ I.R.C. $\S 1061(\mathrm{~d})(1)(\mathrm{A})$.
}

Pitt Tax Review | ISSN 1932-1821 (print) 1932-1996 (online) DOI 10.5195/taxreview.2018.80 | http://taxreview.law.pitt.edu 


\section{$100 \mid$ Pittsburgh Tax Review | Vol. 162018}

described above, it is potentially very inefficient from a tax perspective to move assets out of corporate solution, whether such movement is accomplished by an actual distribution, a check-the-box election, or a corporate transaction such as a merger into a pass-through entity. An $\mathrm{S}$ corporation election may often be accomplished on a tax-efficient basis, but there are limitations on which corporations may make the $\mathrm{S}$ corporation election, and the benefits that are derived from the election are often less than those available to a non-S corporation pass-through entity.

The bottom line is that the choice-of-entity analysis has become even more difficult in the post-TCJA world. As discussed above, old thinking retains some validity, but the new provisions of the TCJA should cause every business or investment entity, new and existing, to revisit the choice-of-entity decision. Of course, the costs associated with changing the tax classification of an existing entity must be considered as part of the conversation, but that is a topic for another article.

Pitt Tax Review | ISSN 1932-1821 (print) 1932-1996 (online) DOI 10.5195/taxreview.2018.80 | http://taxreview.law.pitt.edu 